Article

The Fury of the Mysterious Coronavirus

(COVID 19) - A General Perspective

Journal of Development Economics and

Management Research Studies (JDMS),

A Peer Reviewed Open Access International

Journal

ISSN 25825119 (Online)

04(04), 67-76, April-June, 2020

@ Center for Development Economic Studies

(CDES)

Reprints and permissions

http://www.cdes.org.in/

http://www.cdes.org.in/journal/

\title{
The Fury of the Mysterious Coronavirus (COVID 19) - A General Perspective
}

\author{
Dr. V. Manikantan ${ }^{1}$
}

\begin{abstract}
Coronavirus (Covid 19) is the most contagious disease which was spread from China. China is the epicenter of the dangerous disease. Majority of contagious diseases are caused from China. The measures taken to control the same was not that easy in earlier days. The World Health Organization plays an important role in confirming about any disease and about the virulence of the disease in any country. But it is alleged to be failed in the case of COVID 19. This paper focuses about the possible reasons of the outbreak of the pandemic, its impact on global economy and Indian Economy and also attempts to suggest measures to the government and public in order to reduce the severity of the impact. The paper is based only on the secondary data which are mainly the reports collected from the media, social media, news papers and other literatures.
\end{abstract}

Keywords: Coronavirus, Chinese Government, Impact, Global, India, Economy.

\section{Introduction}

The city "Wuhan" is the conglomeration of the names of the three towns namely Wuchang, Hankou and Hanyang. It is the capital city of Hubei province and also the most populous city of Central China. It consists of dozens of railways, expressways and roads connecting the major cities. So it is called as the major transportation hub. This has made it to be considered as "The Chicago of China". Important metropolises in China, including Beijing, Shanghai, Guangzhou, Chengdu, and Xi' an, are all within 1,200 km of Wuhan.

\section{Wuhan - The Trade Hub}

Wuhan is considered an important center for trade, economy, finance, transportation and IT in China. Wuhan's major industries include optic-electronic, automobile manufacturing, iron

\footnotetext{
${ }^{1}$ Head, Departments of Accounting \& Finance and Bank Management, Ramakrishna Mission Vivekananda College Evening College (AUTONOMOUS), Mylapore, Chennai - 4
} 
and steel manufacturing, new pharmaceutical sector, biology engineering, new materials industry. Wuhan had even served as the capital of China in 1927 under the left wing of Kuomintang (KMT) government.

Wuhan has attracted foreign investment from over 80 countries. It has a direct competition with first-tier cities of China like Shanghai, Beijing and Guangzhou when it comes to domestic trade in terms of volume of retail. Wuhan, currently, has over 300 British-funded firms with a total investment of 5 billion USD. Wuhan has attracted more than 50 French companies. Canada has a number of bilateral trade and investment policy instruments in place that are helping to facilitate and support Canadian commercial engagement. The main export destinations of Wuhan includes, U.S., South Korea, Netherlands, India, Germany, Japan, U.K., Singapore, Brazil, for supplying Machinery, electrical machinery, iron and steel, organic chemicals, woven apparel, preserved foods, automotive vehicles. The main import sources are Japan, South Korea, Taiwan, U.S., Germany, Australia, Malaysia, Saudi Arabia and Brazil for Ores/Slag/Ash, machinery, electrical machinery, automotives, optic and medical instruments, iron and steel, glass and glassware, plastic, aircrafts/space craft's. This is very clear that major countries of the world were having more trade relationship with China and were dependent on many vital produces. In terms of trade, China is the world's largest exporter and second-largest importer. It accounts for $13 \%$ of world exports and $11 \%$ of world imports.

\section{Review of Literature}

Sunil Kumar had opined in their article that globally Coronavirus has produced an unstable environment for people. This pandemic has stopped many of economic activities due to contagious disease and has no cured till date to fight with corona. They have also focused about the impact of Covid 19 in the various sectors of our Indian industry. Sakir Mahmud in his article, he has stated that the World economy is interrelated and is closely integrated. Any mishap in any part of the world will have serious impact on the entire other parts of the world too. He has also described about role of China in the Machine and electrical \& electronic industry towards other countries and how the situation is highly uncontrollable due to this pandemic as China is the epicenter.

Ghada M Abaido and A Takshe (March 2020), in their article, they had made an attempt to understand the reasons of the widespread attention received by COVID 19. They also attempted to understand the role of media played in creating the attention about this Covid 19. At the dawn of 2020, several pneumonia cases were reported in the city of Wuhan, China that was caused by the novel Coronavirus. Pranab Chatterjee opines that the emergence of SARS-CoV-2 has once again exposed the weaknesses of global health systems preparedness, ability to respond to an infectious threat, the rapidity of transmission of infections across international borders and the ineffectiveness of knee-jerk policy responses to emerging/re-emerging infectious disease threats. The review concludes with the key learning points from the ongoing efforts to prevent and contain COVID-19 and identifies the need to invest in health systems, community-led response mechanisms and the need for preparedness and global health security. 


\section{About Coronavirus (COVID 19)}

As we have seen about Wuhan as a trade hub, we can understand that it is one of the important districts of China. The people of China are known for their weird eating habits. They eat snakes, pangolians, bats, scorpions and many more. Dr. Shi Zhengli is one of the researchers in the Wuhan Institute of Virology. She is considered to be one of the active Coronavirus researchers. She was considered as the Bat Lady as she had spent most of her life in researching about Bats which lived in caves. Dr. Shi Zhengli finds out that there was a similarity with the genome of the Coronavirus to an extent of $96.2 \%$ matching with the virus present in the Horseshoe Bats which are seen in the caves of Yunnan, a place in China.

\section{Outbreak of the Pandemic Coronavirus - COVID19}

Deep secrets of the P4 Wuhan laboratory have been exposed through documents, photographs about the virus leak. The disclosures in the documents, photos, raise disturbing questions. After this outbreak, there has been a huge amount of focus on the alleged culpability of the Chinese establishment in spreading this virus and not doing enough to alert the world about the virulence of this virus. There is a leak thesis. It was told that $96.2 \%$ genome was similar to the viruses present in bat. There were many contradictions. After the outbreak, the Wuhan institute of Virology was strangely silent. The institute was considered to be the Virus Bank. It used to contain and safeguard many kinds of virus sealed in its laboratory. In one of the works of Mr. Joshua Philipp, Senior Investigative Reporter of EPOP TIMES, it is mentioned that every disease that begins in China is from Guangdong Province which is near Honking. But it was very unusual to have Covid 19 beginning from Wuhan, the Central part of China. It is also mentioned in his report that since the outbreak, there held many abnormal events in Wuhan:

$\checkmark \mathbf{2}^{\text {nd }}$ January 2020, an order was issued to the Director General of the Wuhan Institute of Virology and the authority issued a strict prohibition upon the disclosure of strange pneumonia prevailing in the city. The National Health Commission of China had clearly instructed that no details relating to the virus shall be published through articles nor be published in any media or even in social media.

$\checkmark 21^{\text {st }}$ January 2020, a new drug, "Remdesivir" provided free from U.S. to China for Wuhan Coronavirus treatment was patented by Wuhan Institute of Virology.

$\checkmark 3^{\text {rd }}$ February 2020, Dr. Wu Xiaohua, blew the whistle that Dr. Shi Zengli's haphazard laboratory management may have led the Wuhan virus to leak from the lab.

$\checkmark 4^{\text {th }}$ February 2020, Chairman of Duoyl, Mr. Xi Bo mentioned that the Wuhan Institute of Virology was suspected of manufacturing and leaking the Wuhan virus.

$\checkmark 7^{\text {th }}$ February 2020, Top Bio Chemical weapon expert of the People's Liberation Army Mr. Chen Woi, officially assumed control over Wuhan Institute of Virology's P4 laboratory.

$\checkmark \quad 1^{\text {th }}$ February 2020, the institute refused widely spread rumors on Chinese social media that female graduate Huang Yanding was patient zero and had perished. However Huang's photo, CV, and thesis were all removed from the Institute's official website, leaving only her name. 
$\checkmark \quad 7^{\text {th }}$ February 2020, Ms. Chen Quanjia, a researcher in the institute, blew the whistle that the Director General of the institute Dr. Wang Yanyi was suspected of leaking the virus.

$\checkmark$ Despite of all the above, the Chinese government has rejected the claims and said the WHO (World Health Organization) found no proof that the virus has originated from the lab of Wuhan and also said that the allegations are not only false in nature but also impossible.

\section{Negligence in proper investigation by World Health Organization}

A single tweet from the WHO account on January 14 expressing that, "Preliminary investigations conducted by the Chinese authorities have found no clear evidence of human-tohuman transmission of the novel Coronavirus." Similarly on the same day, the Wuhan Health Commission's public bulletin declared, "We have not found proof for human-to-human transmission." But by that point even the Chinese government was offering caveats not included in the WHO tweet. "The possibility of limited human-to-human transmission cannot be excluded," the bulletin said, "but the risk of sustained transmission is low." This, we now know, was catastrophically untrue, and since then, the global pandemic has spread even on the other parts of world where many countries had to declare an unprecedented lockdown. And at the same time, the outbreak of the pandemic had also killed more than 100,000 people. On January 20, a Chinese official publically declared for the first time that the virus could indeed spread among humans. But by then it was too late. It took another week for the WHO to declare the spread of the virus a global health emergency - during which time Dr. Tedros Adhanom Ghebreyesus, the WHO's director-general, visited China and praised the country's leadership for "setting a new standard for outbreak response." Another month and a half went by before the WHO called COVID-19 a pandemic, at which point the virus had killed more than 4,000 people, and had infected 118,000 people across nearly every continent. This is obvious about the negligence of responsibility of the World Health Organization.

\section{Five Shocking Coronavirus facts, the Chinese refuse to reason out}

Unfortunately, the Chinese Government is forced to answer certain uncomfortable and at the same time unavoidable questions in the international court of law. It is in the opinion of the world leaders that why is that the Chinese Government is unable to give out concrete answers and accept responsibility with reasons when they seek clarifications. The leaders of various countries wanted to know an explanation about the following:

\section{Gag Order}

A high profile investigative report has accused Chinese officials of ordering labs to stop testing and destroy all samples of the Coronavirus in the very early stages of the outbreak. The date was more than a week before the first patient in Wuhan, a 61 - year old man passed away of the virus on $9^{\text {th }}$ January 2020. 


\section{Downplaying}

The government officials downplayed the severity of the virus and tightly controlled the information related to it including its ability to transmit from person to person. It was all done in order to have the communist conference and the New Year celebrations. Despite the cases of infected doctors and Dr. Li's demise, the Wuhan Health Commission did not acknowledge that there was human to human transmission until more than 3 weeks later. The authorities also allowed continuing travel as usual. Around five million Wuhan residents evacuated the place before all forms of transport were halted on $23^{\text {rd }}$ January 2020.

\section{The Trumpet Blowers}

Eight Wuhan medicals workers who signaled and intimated about the virus at the end of December were accused of spreading fake news and reprimanded by police. It was reported that Dr. Li Wenliang warned his colleagues in December 2019 about the outbreak of illness causing severe acute respiratory syndrome. But he was reprimanded by security officers for spreading rumours. In a tragic turn of events, he subsequently contracted Coronavirus and, after a period of intensive care he passed away.

\section{The mysterious zero case days}

Wuhan reported no new cases between $6^{\text {th }}$ January and $17^{\text {th }}$ January when the city was holding a series of important conferences, known as the "Two Sessions". Nearly 700 officials, law makers, government representatives attended the conferences. Furthermore, officials of the Wuhan community organized a huge banquet on $18^{\text {th }}$ January 2020, on account of Lunar New year, inviting 40, 000 families. The 12 days would have been critical in preventing the virus from spreading, but the officials either reported zero cases or did not reported release a daily update.

\section{Disappearing Cell phone users}

China reported 3, 277 fatalities from 81, 171 bacterial infections at the beginning of April. But a report observed the troubling disappearance of some 21 million cell phone accounts in China about the previous three months - an unprecedented decrease that hints at much more fatalities than Beijing geared up to confess.

\section{Some Conspiracy Theories about the outbreak of the Pandemic Covid 19}

Chinese President Xi Jinping's Chinese Dream is described as achieving the "Two 100s", namely the material goal of China becoming a "moderately well-off society" by 2021, and the modernization goal of China becoming a fully developed nation by 2049, the 100th anniversary of the founding of the People's Republic. As China's economy grows, so does China's Renminbi, which undergoes the process needed for its internationalization. This requires elimination of competition and the Chinese Government must establish Monopoly in major sectors of world trade sectors.

Coronavirus (Covid 19) is considered to be a bio weapon engineered by the Chinese Government to wage war on America. Due to the recent history of strained diplomatic relations 
between the two countries, it makes sense that some would speculate that Covid 19 was covertly engineered in a lab as part of an extended campaign to weaken the opposing country. In the meantime, media also expresses that the Chinese Government also blames by claiming that the virus was sent into China by the U.S. through its army for which no proper evidence is available.

Some theorists suggest that the government purposely released it in order to get rid of the old people, pensioners which will thereby bring down the pension costs. China has developed a significant social security system, but with the number of retirees increasing exponentially, it is reaching its limits. The Chinese government is now grappling with the problem of an ageing population. This, combined with the lack of transparency around China's bio safety regulations, allowed the conspiracy theory to spread, largely untested.

\section{Downfall in World Economies}

After the outbreak of the Covid 19, most of the countries have declared lockdown and their both domestic and international borders have been closed. The trade affairs have completely halted. Most of the territories have been reported with a spike in infections and death rates. In some places, polices or even soldiers are patrolling for the safety purposed. The outbreak and irresponsible act of the Chinese Government and WHO has devastated the affairs of many countries. Many countries have been shattered due to the spread of this virus. The analysis by the UN Department of Economic and Social Affairs (DESA) said the COVID-19 pandemic is disrupting global supply chains and international trade. The global economy could shrink by up to 1 per cent in 2020 due to the Coronavirus pandemic, a reversal from the previous forecast of 2.5 per cent growth. Purchasing Managers' Index (PMI) surveys from Japan showed the services sector shrinking at its fastest pace on record this month and factory activity contracting at its quickest in a decade. In Australia, the CBA Services PMI fell to a record low of 39.8 as restaurants, cafes and tourism were hit hard by travel bans and cancellations of events and concerts. The euro zone composite PMI is expected to come in at 38.8, the lowest since early 2009. U.S. manufacturing and services PMIs are also expected at multi-year lows of 42.8 and 42.0 , respectively.

Goldman Sachs warned the U.S. economy could contract by an annual rate of $24 \%$ in the second quarter, two-and-a-half times greater than the previous biggest contraction in the period after World War II. New Zealand said on Tuesday that retail banks will offer a six-month principal and interest payment holiday for mortgage holders and small business customers whose incomes have been affected by the economic disruption from COVID-19. "Despite aggressive moves by central banks, investors remain unconvinced that any of these actions will be enough to stave off the ill effects from (the virus)," says Mr. Prakash Sakpal, ING Asia economist. Mr. Liu Zhenmin, Under-Secretary-General for Economic \& Social Affairs, said, that "Urgent and bold policy measures are needed, not only to contain the pandemic and save lives, but also to protect the most vulnerable in our societies from economic ruin and to sustain economic growth and financial stability," 


\section{Impact of Coronavirus in Indian Economy}

In imports, the dependence of India on China is huge. For automotive parts and fertilisers China's share in India's import is more than 25\%. Around 65 to $70 \%$ of active pharmaceutical ingredients and around $90 \%$ of certain mobile phones come from China to India. Therefore, we can say that due to the current outbreak of Coronavirus in China, the import dependence on China will have a significant impact on the Indian industry. Also, a supply chain may affect some disruptions associates with industries and markets.

An outbreak of COVID-19 impacted the whole world and has been felt across industries. World's second-largest economy China became standstill. Its outbreak is declared as a national emergency by the World Health Organisation. In India the three major contributors to GDP namely private consumption, investment and external trade will all get affected. And business activity in the foreign markets is slow which implies a negative impact on the top line of these companies.

According to KPMG, the lockdown in India will have a sizeable impact on the economy mainly on consumption which is the biggest component of GDP. Reduction in the urban transaction can lead to a steep fall in the consumption of non-essential goods. Due to weak domestic consumption and consumer sentiment, there can be a delay in investment which further add pressure on the growth. According to the KPMG report "It is expected that the course of economic recovery in India will be smoother and faster than that of many other advanced countries". World and Indian economy are attempting to mitigate the health risks of COVID-19 with the economic risks and necessary measures will be taken to improve it.

\section{Suggestions \& Conclusions}

\section{Attending to Social needs actively by the Government}

India must not stop agriculture productivity during lock down. Agriculture must definitely be entertained in order to avoid food scarcity and will also enable the farmers to lead life. Inter-state movement of the raw materials of the agriculture and food industry must not be hampered. More NGO food camps must be entertained for taking care of stray people and migrant daily laborers. Every state must improve the vigilance in the containments and nearby areas with adequate medical care and sanitation. Strict action must be incorporated on violators and carefree stray people. The respective officials must ensure the proper supply of essential requirements in each area periodically. The Government must not entertain the relaxing of domestic gateways for aviation industry until there is a concrete remedy medicinally found.

\section{Future Economic growth expected}

We can't ignore that post-COVID-19, some economies are expected to adopt de-risking strategies and shift their manufacturing bases from China. Countries like Japan, South Korea, and Germany has paid huge amount of money to its companies which have been established in China. This can create opportunities for India. They are likely to have their trade activities with India in future which will in a way help our country to stabilize. The International Monetary 
Fund projection for India for the financial year 2021-22 of 1.9\% GDP growth is the highest among G-20 nations which is a scope for positivity and industrial development as well.

\section{Coronavirus is a wakeup call for global food systems}

The nutritionists, agronomists and sociologists from 18 countries, added that current industrial agriculture models drive habitat loss and create conditions for viruses to emerge and spread through intensive livestock production and an increase in human - wildlife interaction. Intensive livestock production amplified the risk of diseases as a large number of animals are confined in small spaces. This confinement results in narrow generic diversity, fast animal turnover and habitat fragmentation through expansion of livestock production. More than $70 \%$ of infectious diseases like Ebola, SARS, MERS, West Nile Fever, Lyme disease, etc., emerged in humans since 1940 could be traced back to animals. All these rooted in environmental changes and ecosystem disturbances, said IPES - Food. More than 50\% of farmers and rural workers live below the poverty line in different countries across the global south. There must be a paradigm shift to diversified resilient agro-ecological food systems. The Agro-ecological food systems increase disease resistance by re-localising and decentralizing breeding of plants and livestock to harness diversity.

\section{Public Cooperation \& Social Responsibility}

The general public is required to maintain social distancing. This is a disease and it is not to be meant for making politics or preaching religion. Our country is a secular and democratic country. India is also considered to be the youngest country in the world. Today, India is one of the youngest countries in the world with more than $62 \%$ of the population in the working age group (15-59 years) and more than $54 \%$ of the total population below 25 years of age. It is the responsibility of our youngsters to have knowledge about the intensity and the danger of the disease and be cautious. They are also expected to educate the people who are ignorant and those who behave in an irresponsible manner. They may even seek the government officials who are patrolling. The severity of the disease is indescribable. WHO has also suggested that it would be appreciated if we follow social distancing till 2022 until proper vaccine or medicine is invented. More number of celebrities, industrialists like Ratan Tata, Ambani, etc. must come forward to generously contribute financially for the growth and stability of the Economy.

\section{General Hygiene Practices}

WHO (World Health Organisation), has suggested the guidelines for personal hygiene as precautionary steps. They are:

a. We have to wash our hands with soap periodically,

b. Maintain social distancing,

c. Cover the mouth, nose while coughing,

d. not to touch eyes, nose, face or ears unnecessarily,

e. Avoiding contact with anyone who is showing symptoms of respiratory illness like coughing and sneezing. 
We must definitely observe the guidelines and also the other instructions laid by the State \& Central Government based on the situation. We must neither refrain nor resist doing so. It is to be understood that this disease is not that light to take it easy. It is very dangerous and severe. Though there are many challenges been faced on day to day life, at the end of the day we have to live our life for ourselves and for our dependents. We have to understand this and cooperate with the Government. People of many developed countries and small countries are also suffering in the line of same aspects, but it is understandable that our country cannot withstand poverty. Still, let us stay home, and stay safe.

We have to trust and hope for the best to happen. To adopt social distancing it requires an immense control and consciousness. Lockdowns and closure of district borders, state borders, international borders, restricting commutation other than essential requirements and services has to be adhered. Increasing the pace and resource mobilization for research in order to create a drug / vaccine to curb this disease is a need of the hour. This can be efficiently and more effectively done only by the coordination and cooperation of the international community.

\section{References \& Endnotes}

1. Sunil Kumar, (2020): Impact of Coronavirus (Covid 19) in Indian Economy, Agriculture \& Food e-News Letter - ISSN -2581 - 8317, Volume 2 - Issue 4 - April 2020, (Agricultural Extension) ICAR-IARI, New Delhi, \& Ms. Prathiba B Thombare (Home Science), Krish Vigyan Kedra, Kholapur, Mr.Pandurange A Kale, (Agronomy) Krish Vigyan Kedra, Kholapur

2. Sakir, Mahmud, (2020): Impact of Coronavirus in Global Economy, Shahajal University of Science and Technology, February 2020, https://www.researchgate.net/publication/339435164_Impact_of_Corona_Virus_on_the_ Global_Economy

3. Ghada M Abaido, (2020): Covid 19 - Virus or Viral Conspiracy Theories? Department of Communication, Arts \& Science, Canadian University of Dubai, UAE, and Ms. A Takshe, Department of Environmental Health Science, Arts \& Science, Canadian University of Dubai, UAE (March 2020) - American Journal of Biomedical Science and Research - ISSN - $2642-1747$

4. Pranab Chatterjee, (2020): The 2019 novel Coronavirus disease (COVID-19) pandemic: A review of the current evidence, Translational Global Health Policy Research Cell, Indian Council of Medical Research, New Delhi, India, DOI: 10.4103/ijmr.IJMR_519_20, PMID: 32242874 http://www.ijmr.org.in/preprintarticle.asp?id=281608;type=0 (Article coming soon)

5. https://www.indiatoday.in/fyi/story/why-is-china-s-wuhan-important-for-india-12215022018-04-27

6. https://www.tradecommissioner.gc.ca/china-chine/market-facts-faits-sur-lemarche/96289.aspx ?lang=eng

7. https://en.wikipedia.org/wiki/Economy_of_China

8. www.facebook.com/worldofweird/shocking conspiracy theories and rumors about Coronavirus/Mar28 at 22:23

9. www.facebook.com/worldofweir/videos/257575718971270/ April13 at 6:15

10. https://www.facebook.com/Timesnow/videos/668873110353311/April 20 at 22:222 
11. "Xi Jinping's Chinese Dream". The New York Times. 4 June 2013. Archived from the original on 4 November 2016. Retrieved 18 February 2017.

12. "Currency Reform" (PDF). brookings.edu. Archived (PDF) from the original on 2 April 2015. Retrieved 28 March 2015.

13. https//www.facebook.com/dinamalrdaily/videos/527362107982072/April 18 at 21:20

14. https://www.theatlantic.com/politics/archive/2020/04/world-health-organization-blamepandemic-coronavirus/609820/

15. https://economictimes.indiatimes.com/news/international/business/global-economycould-shrink-by-almost-1-in-2020-due-to-covid-19-pandemic-unitednations/articleshow/74943235.cms?from $=\mathrm{mdr}$

16. https://economictimes.indiatimes.com/news/international/business/surveys-showcoronavirus-pandemic-savaging-globaleconomy/articleshow/74786359.cms?utm_source=contentofinterest\&utm_medium=text \&utm_campaign=cppst

17. https://www.downtoearth.org.in/news/agriculture/covid-19-iswake-up-call-for-globalfood-systems-says-experts-70558 - 20th April 2020

18. https://www.jagranjosh.com/general-knowledge/what-is-the-impact-of-coronavirus-onindian-economy-1582870052-1

19. https://www.mygov.in/newindia/wpcontent/uploads/2017/09/newindia301634_1504694260.pdf 